\title{
MUSCLE COMPOSITION IN RESPIRATORY ACIDOSIS 1
}

\author{
By ROBERT E. COOKE, ${ }^{2}$ FRANK R. COUGHLIN, JR., ${ }^{3}$ AND WILLIAM E. SEGAR \\ WITH THE TECHNICAL ASSISTANCE OF FRANCES COVILLE
}

\author{
(From the Departments of Pediatrics and Physiology, Yale University School of Medicine, \\ New Haven, Conn.)
}

(Submitted for publication June 16, 1952; accepted August 28, 1952)

The close relationship of muscle composition to the electrolyte pattern of extracellular fluid was described by Darrow (1) and confirmed by others (2). The direct correlation of serum bicarbonate concentration with the intracellular sodium content of muscle in metabolic acidosis and alkalosis was demonstrated by these workers. Until the present time it has not been determined whether this relation of serum bicarbonate to muscle sodium applies in respiratory disturbances of acidbase balance. In these states serum $\mathrm{pH}$ varies inversely with serum bicarbonate concentration or serum $\mathrm{pCO}_{2}$, in contrast to metabolic disturbances in which serum $\mathrm{pH}$ varies directly with serum bicarbonate concentration and serum $\mathrm{pCO}_{2}$. Thus, by the study of tissue composition in respiratory disturbances, it can be established whether muscle composition is related under all circumstances to serum $\mathrm{pH}$, serum bicarbonate concentration or serum $\mathrm{pCO}_{2}$.

This paper presents analyses of serum and muscle of rats in whom respiratory acidosis was induced by inhalation of gas mixtures containing 10 to 15 per cent carbon dioxide for periods of fourteen to twenty-one days.

\section{PLAN OF EXPERIMENTS AND METHODS OF}

\section{ANALYSIS}

Sixteen male albino rats weighing 300 to $400 \mathrm{gm}$. were kept in an air-tight lucite chamber into which was run a mixture of compressed air and carbon dioxide. Group A, eight animals, was exposed to an atmosphere containing 11 per cent $\mathrm{CO}_{2}$ for two weeks. Group $\mathrm{B}$, eight animals, was exposed to 13 per cent $\mathrm{CO}_{2}$ for three weeks. Analysis of the air in the chamber was performed at

1 Aided by research grants from the United States Public Health Service and the James Hudson Brown Memorial Fund of the Yale University School of Medicine.

2 John and Mary R. Markle Scholar in Medical Science.

8 This study represents a portion of the thesis submitted for the degree of Doctor of Medicine, Yale University School of Medicine. frequent intervals throughout the experiments by means of the Roughton Scholander apparatus (3). The oxygen concentration in the chamber did not fall below 17 per cent.

The temperature within the chamber was maintained at $23^{\circ} \mathrm{C}$. and the relative humidity at 80 per cent. The chamber was opened for twenty minutes every three days for the purpose of cleaning the cages and replenishing food ${ }^{4}$ and distilled water.

All animals were anesthetized with ether within one to three minutes after removal from the chamber, and blood was obtained anaerobically from the dorsal aorta immediately thereafter.

The methods used in the analysis of serum and muscle are the same as described earlier by this laboratory (4) except that sodium and potassium were determined by a Barclay internal standard flame photometer. Serum $\mathrm{pH}$ was determined on the Beckman $\mathrm{pH}$ meter using a temperature correction of $0.0118 \mathrm{pH}$ units for each degree of temperature below $38^{\circ} \mathrm{C}$. The $\mathrm{pH}$ of the sera so obtained was not considered representative of the $\mathrm{pH}$ of the animals while in the chamber, since the high alveolar carbon dioxide tension would be rapidly dissipated during anesthesia. The values for $\mathrm{pH}$, bicarbonate and carbonic acid concentrations of serum while in the chamber cannot be determined exactly and were calculated as indicated below.

The average percentage of deviation from the mean of duplicate determinations was as follows:

$$
\mathrm{Cl} \pm 1.0 \% \quad \mathrm{P} \pm 1.1 \% \quad \mathrm{Na} \pm 1.1 \% \quad \mathrm{~K} \pm 1.2 \%
$$

\section{Calculations}

$$
\begin{aligned}
\text { Group A- } & \\
\mathrm{ppCO}_{2} \text { chamber } & =0.11 \times(760-47)=78, \\
\mathrm{pCO}_{2} \text { blood }^{5} & =85 \mathrm{~mm} . \mathrm{Hg} \text { approximately. } \\
\text { Group B- } & \\
\mathrm{ppCO}_{2} \text { chamber } & =0.13 \times(760-47)=93 \\
\mathrm{pCO}_{2} \text { blood }^{5} & =100 \mathrm{~mm} . \mathrm{Hg} \text { approximately. }
\end{aligned}
$$

\section{Group B-}

4 Purina Fox Chow :-Na-34 mM./100 gm.; K-13 mM./100 gm.; Cl-17 mM./100gm. ; N-2.95 gm./100 gm. ; $\mathrm{P}-36 \mathrm{mM} . / 100 \mathrm{gm}$.

5 The percentage of carbon dioxide in the alveolar air must be greater than that in the chamber. Normally, $\mathrm{CO}_{2}$ tension in the lungs is about $40 \mathrm{~mm}$. $\mathrm{Hg}$ greater than in the air. However, Brown, Hemingway, and Visscher

(6) demonstrated a progressive decrease in this gradient 
TABLE I

Body composition in disturbances of acid-base balance

\begin{tabular}{|c|c|c|c|c|c|c|c|c|c|c|c|c|c|}
\hline \multirow{2}{*}{ Group } & \multirow{2}{*}{$\begin{array}{c}\text { Refer- } \\
\text { ence }\end{array}$} & \multicolumn{6}{|c|}{ Serum } & \multicolumn{6}{|c|}{ Muscle per $100 \mathrm{gm}$. FFS } \\
\hline & & $\stackrel{\mathrm{Na}}{\mathrm{mM} . / \mathrm{L} .}$ & $\underset{\mathbf{m} \mathbf{M} . / \mathbf{L} .}{\mathbf{K}}$ & $\underset{\mathrm{mM} . / \mathrm{L} .}{\mathrm{Cl}}$ & $\begin{array}{c}\mathrm{HCO}_{3} \\
\mathrm{mM} . / \mathrm{L} .\end{array}$ & $\mathrm{pH}$ & $\begin{array}{c}\mathrm{pCO}_{2} \\
\mathrm{~mm} . \mathrm{Hg}_{\mathrm{g}}\end{array}$ & $\begin{array}{l}\mathrm{H}_{2} \mathrm{O} \\
\mathrm{gm} .\end{array}$ & $\begin{array}{c}\mathrm{Cl} \\
\mathrm{mM}\end{array}$ & $\underset{\mathrm{mMa}}{\mathrm{Na}}$ & $\underset{\mathbf{m} \mathbf{M}}{\mathbf{K}}$ & $\underset{\mathrm{mM}}{\mathbf{P}}$ & $\begin{array}{l}\text { Nai } \\
\text { mM. }\end{array}$ \\
\hline Normal & $1,2,4,8$ & $141-146$ & $4.1-5.4$ & $99-102$ & $21-25$ & 7.35 & 45 & $334-346$ & $5.1-7.2$ & $9.4-10.6$ & $46.1-48.9$ & $32.0-34.0$ & 3.1 \\
\hline $\begin{array}{c}\text { acidosis } \\
\text { A } \\
\text { B } \\
\text { Metabolic }\end{array}$ & $\begin{array}{l}- \\
- \\
8\end{array}$ & $\begin{array}{c}136-147 \\
(141)^{*} \\
142-144 \\
(143) \\
151\end{array}$ & $\begin{array}{c}4.3-5.3 \\
(5.1) \\
4.5-5.0 \\
(4.8) \\
3.4\end{array}$ & $\begin{array}{c}90-96 \\
(93) \\
82-87 \\
(85) \\
87\end{array}$ & $\begin{array}{c}31-37 \\
(32) \\
37-46 \\
(40) \\
35\end{array}$ & $\begin{array}{l}7.25 \dagger \\
7.24 \dagger \\
7.44\end{array}$ & $\begin{array}{r}85 \\
100 \\
53\end{array}$ & $\begin{array}{c}312-335 \\
(326 \pm 7) \\
320-359 \\
(333 \pm 12) \\
314\end{array}$ & $\mid \begin{array}{c}4.7-5.8 \\
(5.0 \pm 0.4) \\
4.8-5.7 \\
(5.3 \pm 0.4) \\
3.9\end{array}$ & $\begin{array}{c}8.4-9.7 \\
(9.0 \pm 0.4) \\
7.3-9.8 \\
(8.8 \pm 0.9) \\
11.9\end{array}$ & $\begin{array}{c}47-49 \\
(48 \pm 1) \\
47-50 \\
(48 \pm 1) \\
37.8\end{array}$ & $\begin{array}{c}32-34 \\
(33 \pm 1) \\
32-35 \\
(33 \pm 1) \\
30.4\end{array}$ & $\begin{array}{c}3.3-3.8 \\
(3.5 \pm 0.2) \\
1.1-3.3 \\
(2.2 \pm 0.8) \\
7.7\end{array}$ \\
\hline $\begin{array}{c}\text { alkalosis } \\
\text { Metabolic }\end{array}$ & 8 & 142 & 6.7 & 94 & 20 & 7.28 & 44 & 337 & 4.5 & 6.1 & 49.8 & 33.2 & 1.6 \\
\hline $\begin{array}{l}\text { acidosis } \\
\text { Respiratory al- } \\
\text { kalosis (alti- } \\
\text { tude) }\end{array}$ & 9 & 143 & 5.6 & 124 & $\downarrow$ & $\uparrow$ & $\downarrow$ & 342 & 9.1 & 12.0 & 45.0 & 32.5 & 3.5 \\
\hline $\begin{array}{l}\text { tude) } \\
\text { H. R. } \\
\text { muscle }\end{array}$ & $\overline{7}$ & 135 & 5.2 & 80 & 46 & - & - & $\begin{array}{c}366 \\
360-400\end{array}$ & $\begin{array}{c}13.0 \\
12-15\end{array}$ & $\begin{array}{c}20.0 \\
16-22\end{array}$ & $\begin{array}{c}42.4 \\
41-44\end{array}$ & 二 & $2-6$ \\
\hline
\end{tabular}

* Mean.

† Calculated from carbon dioxide content and probable $\mathrm{pCO}_{2}$ of alveolar air while in chamber.

$\mathrm{pH}_{\text {ser }}{ }^{6}$ of animals while in the chamber was calculated from the Henderson-Hasselbach equation using $\mathrm{pCO}_{2}$ above and carbon dioxide content obtained by analysis plus $5 \mathrm{mM}$. per liter for the change in cation-binding capacity of blood proteins with change in $\mathrm{pH}$ as described by Singer and Hastings (5). The rapid loss of dissolved $\mathrm{CO}_{2}$ which occurred during exsanguination produced marked change in the serum $\mathrm{pH}$, but would have relatively less effect on the serum carbon dioxide content.

$\left[\mathrm{H}_{2} \mathrm{CO}_{3}\right]_{\mathrm{ser}}$ in $\mathrm{mM} . / \mathrm{L} .=\mathrm{pCO}_{2} \times .0301$, $\left[\mathrm{HCO}_{3}\right]_{\mathrm{ser}}$ in $\mathrm{mM} . / \mathrm{L}$.

$$
=\mathrm{CO}_{2} \text { content }-\left[\mathrm{H}_{2} \mathrm{CO}_{3}\right]_{\mathrm{ser}} \text {. }
$$

Electrolyte concentration of extracellular fluid as $\mathrm{mM} . / \mathrm{Kg}$. of water was calculated by the method described by Yannet and Darrow (4).

$$
\begin{aligned}
& \frac{[\mathrm{Cl}]_{\text {ser }}}{\left[\mathrm{H}_{2} \mathrm{O}\right]_{\mathrm{ser}} \times 0.95}=[\mathrm{Cl}]_{\mathrm{e}} \\
& \frac{[\mathrm{Na}]_{\text {ser }} \times 0.95}{\left[\mathrm{H}_{2} \mathrm{O}\right]_{\text {ser }}}=[\mathrm{Na}]_{\mathrm{e}} \\
& {[\mathrm{K}]_{\mathrm{e}}=[\mathrm{K}]_{\mathrm{ser}}}
\end{aligned}
$$

as the environmental $\mathrm{CO}_{2}$ pressure increased. The assumption that the alveolar pressure of $\mathrm{CO}_{2}$ in this experiment is $7 \mathrm{~mm}$. $\mathrm{Hg}$ higher than that of the atmosphere would seem to be a reasonable one.

- Subscripts "ser," "e," and "i" refer to serum, extracellular, and intracellular phases, respectively.

( ) refers to total amount in $\mathrm{mM}$. or $\mathrm{gm}$.

[ ] refers to concentration.
Muscle per 100 gram fat-free solids (FFS)

$$
\begin{aligned}
&\left(\mathrm{H}_{2} \mathrm{O}\right)_{e} \text { in grams }=\frac{(\mathrm{Cl}-1)}{[\mathrm{Cl}]_{e}} \\
&(\mathrm{Na})_{e} \text { in mM. }=\left(\mathrm{H}_{2} \mathrm{O}\right)_{e} \times[\mathrm{Na}]_{e} \\
&(\mathrm{Na})_{i} \text { in mM. }=(\mathrm{Na})-(\mathrm{Na})_{e} . \\
& \text { RESULTS }
\end{aligned}
$$

All animals tolerated the experiment well with little overall change in weight in either group. Hyperpnea was evident early in the experiment, but activity was not obviously diminished. Analysis of serum in both groups revealed a marked rise in serum carbon dioxide content and fall in serum chloride concentration from the normal (Table I) -changes characteristic of chronic respiratory acidosis. The mean total serum carbon dioxide content in Group A was $35 \pm 2 \mathrm{mM}$./L. and in Group B, which was exposed to 12 to 15 per cent $\mathrm{CO}_{2}$ for three weeks, it was $43 \pm 3 \mathrm{mM}$./L. Since the carbon dioxide concentration in the alveolar air must have been higher than the concentration in the chamber, the $\mathrm{pCO}_{2}$ of arterial blood was at least $85 \mathrm{~mm}$. $\mathrm{Hg}$ in Group $\mathrm{A}$ and 100 $\mathrm{mm}$. $\mathrm{Hg}$ in Group B. These values correspond to carbonic acid concentrations of $2.6 \mathrm{mM}$./L. and $3.0 \mathrm{mM}$./L. respectively. Thus the mean serum bicarbonate concentration by calculation was $32 \pm$ $2 \mathrm{mM}$./L. in Group $A$ and $40 \pm 3 \mathrm{mM}$./L. in Group B.

The mean serum $\mathrm{pH}$ of animals in Group $\mathrm{A}$ 
while in the chamber was calculated to be 7.25 , whereas Group B averaged 7.24.

The serum chloride concentration was low in each group, $93 \pm 2 \mathrm{mM}$./L. and $85 \pm 2 \mathrm{mM}$./L. in Groups A and B, respectively.

The serum sodium and potassium concentrations were not significantly altered in either group, although the mean potassium concentration was at the upper limit of normal.

The analysis of skeletal muscle from these animals revealed relatively little change from normal composition (Table I). The changes in Group B were somewhat greater than in Group A. The sodium content was $8.8 \pm 0.9 \mathrm{mM} . / 100 \mathrm{gm}$. FFS in Group B. This value was slightly lower than the normal range (9.4-10.6 mM./100 gm. FFS) obtained by Darrow (1). The muscle potassium (48 $\pm 1 \mathrm{mM} . / 100 \mathrm{gm}$. FFS) was at the upper limit of the normal range $(46.1-48.9 \mathrm{mM} . / 100$ gm. FFS). The chloride and phosphorous content of muscle was within normal limits (5.3 \pm $0.4 \mathrm{mM} . / 100 \mathrm{gm}$. FFS and $33 \pm 1 \mathrm{mM} . / 100 \mathrm{gm}$. FFS, respectively).

The derived values for intracellular sodium $(\mathrm{Na})_{1}$ of muscle were somewhat lower than normal. The mean $(\mathrm{Na})_{1}$ for Group $\mathrm{B}$ was $2.2 \pm$ $0.8 \mathrm{mM} . / 100 \mathrm{gm}$. FFS in contrast to the normal value of $3.1 \mathrm{mM} . / 100 \mathrm{gm}$. FFS given by Darrow (1).

The water content of muscle was not significantly altered but the extracellular phase may have been decreased in Group A.

Analysis of human muscle (H. R.-Table I) obtained at postmortem examination from a patient with chronic respiratory acidosis on a basis of cystic fibrosis of the lungs and pancreas revealed findings similar to those described above in rats. Table I also shows the composition of normal human muscle (7). Human muscle potassium is lower than that of rats, probably 40 to $44 \mathrm{mM}$. per $100 \mathrm{gm}$. of fat-free solids. The analyses are shown to demonstrate that marked changes in intracellular $\mathrm{Na}$ and $\mathrm{K}$ did not occur in one patient dying with extremely high total $\mathrm{CO}_{2}$ due to compensated respiratory acidosis.

\section{DISCUSSION}

The results of this study indicate that muscle composition is not especially altered in chronic re-

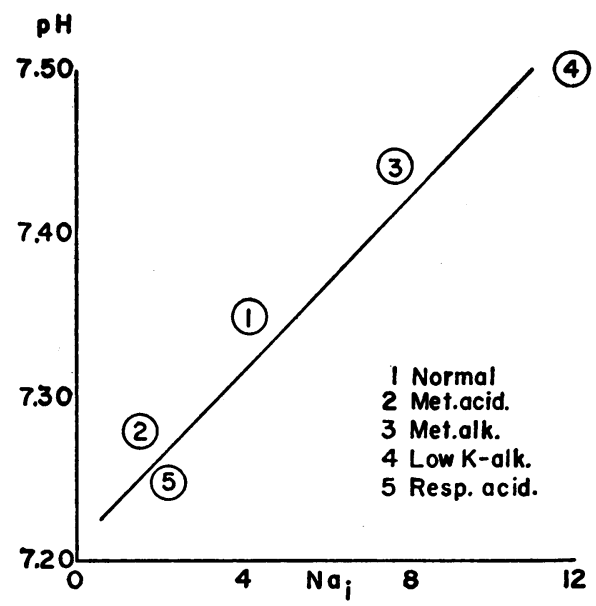

Fig. 1. Relation of Intracellular Sodium of MusCle in MM./100 GM. FFS to PH of Extracellular FLUID

References and values from Table I.

spiratory acidosis, despite the presence of low serum chloride concentration and high serum bicarbonate concentration in this condition. The changes in muscle composition which do occur are in the same direction as those noted in metabolic acidosis (Table I) rather than metabolic alkalosis.

If the values for serum bicarbonate and intracellular sodium in respiratory acidosis are plotted on the graph formulated by Darrow and his associates (1) for animals with metabolic acidosis, metabolic alkalosis, and potassium deficiency alkalosis, there is wide variance from the regression line previously calculated.

Similarly, if $(\mathrm{Na})_{1}$ of muscle is plotted against the $\mathrm{pCO}_{2}$ of serum as calculated from the data of Cotlove and his associates (8) and the present data, no correlation is noted.

However, in Figure 1, serum $\mathrm{pH}$ in all these disturbances, respiratory and metabolic, is plotted against $(\mathrm{Na})_{1}$. It is obvious that there is a direct relation between intracellular sodium and extracellular $\mathrm{pH}$ in all these states. Likewise muscle potassium varies inversely with serum $\mathrm{pH}$.

These findings are consistent with the data of Darrow and Sarason (9) who demonstrated slightly high intracellular muscle sodium and somewhat low muscle potassium in rats exposed to low atmospheric pressures. These animals undoubtedly had some degree of respiratory alkalosis secondary to overbreathing (10), since serum so- 
dium was normal and serum chloride was elevated (Table I). Unfortunately serum carbon dioxide content and serum $\mathrm{pH}$ were not obtained.

Thus, it is likely that the loss or gain of potassium or sodium by the cells is dependent not upon extracellular bicarbonate or chloride concentration or carbon dioxide tension, but rather upon the $\mathrm{pH}$ of the extracellular fluid. In general the following predictions may be made:

1. That in chronic states, in which extracellular $\mathrm{pH}$ is elevated, muscle potassium is lowered and intracellular sodium elevated.

2. That in chronic states, in which extracellular $\mathrm{pH}$ is lowered, muscle potassium is normal or elevated and intracellular sodium reduced.

3. That the changes in muscle composition are considerably less in respiratory disturbances of acid-base balance than in metabolic disturbances.

According to the hypothesis of Wallace and Hastings (11) intracellular $\mathrm{pH}$ is dependent upon $\mathrm{PCO}_{2}$ of body fluids since intracellular bicarbonate concentration is constant. According to this concept intracellular acidosis is present in metabolic alkalosis with respiratory compensation, as well as in respiratory acidosis, since $\mathrm{pCO}_{2}$ is elevated in both conditions. However, the composition of muscle was strikingly different in the two types of disturbances. This fact suggests the following alternatives :

1. That electrolyte composition of muscle is not related to intracellular $\mathrm{pH}$ if the hypothesis of Wallace and Hastings is valid, or

2. That electrolyte composition of muscle is related to intracellular $\mathrm{pH}$ and the hypothesis of Wallace and Hastings that intracellular $\mathrm{pH}$ is directly related to $\mathrm{pCO}_{2}$ of body fluids is not valid.

Which proposition is correct cannot be determined at the present time. The data of Conway (12) suggest that a large part of the total acid labile $\mathrm{CO}_{2}$ in muscle measured by Wallace and Hastings may be barium-soluble and hence not bicarbonate. Under these circumstances the $\mathrm{pH}$ within the cell would be 6.0 and small changes in intracellular bicarbonate could not be determined by the methods now available.

The finding of relatively normal muscle composition in respiratory disturbances suggests that cell transfer plays a minor role in the correction of such conditions and that renal compensation is of primary importance. These findings confirm the suspicions of Elkinton, Squires, and Singer in the case of humans with respiratory acidosis (13). Therefore, in the fluid therapy of these states adequate quantities of water and extracellular electrolyte (sodium chloride) should be provided so that complete renal compensation may be effected.

\section{SUMMARY}

Male rats were exposed to an atmosphere containing 10 to 15 per cent carbon dioxide for two to three weeks. Analysis of serum at the end of that time revealed changes characteristic of chronic respiratory acidosis, namely high serum bicarbonate concentration ( $41 \mathrm{mM}$./L.) and low serum chloride $(85 \mathrm{mM} . / \mathrm{L}$.). Analysis of muscle revealed potassium content at the upper limit of normal, $48 \mathrm{mM} . / 100 \mathrm{gm}$. fat-free solids (FFS) and the intracellular sodium was somewhat reduced, $2.2 \mathrm{mM} . / 100 \mathrm{gm}$. FFS. These findings are in striking contrast to those in metabolic alkalosis in which serum bicarbonate concentration is also high and serum chloride low.

It is suggested that muscle composition is related to the $\mathrm{pH}$ of the extracellular fluid and not to the extracellular bicarbonate concentration or carbon dioxide tension.

\section{REFERENCES}

1. Darrow, D. C., Schwartz, R., Iannucci, J. F., and Coville, $F$., The relation of serum bicarbonate concentration to muscle composition. J. Clin. Invest., 1948, 27, 198.

2. Muntwyler, E., Griffin, G. E., Samuelson, G. S., and Griffith, L. G., The relation of the electrolyte composition of plasma and skeletal muscle. J. Biol. Chem., 1950, 185, 525.

3. Scholander, P. F., Analyzer for accurate estimation of respiratory gases in one-half cubic centimeter samples. J. Biol. Chem., 1947, 167, 235.

4. Yannet, H., and Darrow, D. C., The effect of depletion of extracellular electrolytes on the chemical composition of skeletal muscle, liver, and cardiac muscle. J. Biol. Chem., 1940, 134, 721.

5. Singer, R. B., and Hastings, A. B., An improved clinical method for the estimation of disturbances of the acid-base balance of human blood. Medicine, 1948, 27, 223.

6. Brown, E. B., Jr., Hemingway, A., and Visscher, M. B., Arterial blood $\mathrm{pH}$ and $\mathrm{pCO}_{2}$ changes in 
response to $\mathrm{CO}_{2}$ inhalation after 24 hours of passive hyperventilation. J. Applied Physiol., 1950, 2, 544.

7. Mudge, G. H., and Vislocky, K., Electrolyte changes in human striated muscle in acidosis and alkalosis. J. Clin. Invest., 1949, 28, 482.

8. Cotlove, E., Holliday, M. H., Schwartz, R., and Wallace, W. M., Effects of electrolyte depletion and acid-base disturbance on muscle cations. Am. J. Physiol., 1951, 167, 665.

9. Darrow, D. C., and Sarason, E. L., Some effects of low atmospheric pressure on rats. J. Clin. Invest., 1944, 23, 11.
10. Clarke, R. W., Marshall, C., and Nims, L. F., Blood pH during decompression. Am. J. Physiol., 1944, 142, 483

11. Wallace, W. M., and Hastings, A. B., The distribution of the bicarbonate ion in mammalian muscle. $\mathrm{J}$. Biol. Chem., 1942, 144, 637.

12. Conway, E. J., Calculation of the idiomolar value and its electrostatic equivalent in normal mammalian skeletal muscle. Irish J. M. Sc., 1950, No. 293, 216.

13. Elkinton, J. R., Squires, R. D., and Singer, R. B., Intracellular cation exchanges in acidosis due to renal insufficiency. Effects of alkali therapy. J. Clin. Invest., 1951, 30, 381. 